\title{
The antibacterial biofilm activity of metal-doped mullite ceramics against pathogenic bacteria
}

\author{
Suzan A. Matar ${ }^{1}$, Eman M. Mahmoud ${ }^{2}$, and Hamdallah A. Hodali ${ }^{2 *}$ \\ ${ }^{1}$ Department of Biology, Faculty of Sciences, The University of Jordan, Amman 11942, Jordan. \\ ${ }^{2}$ Department of Chemistry, Faculty of Sciences, The University of Jordan, Amman 11942, Jordan.
}

Accepted 10 May, 2013

\begin{abstract}
Bacterial biofilms are densely packed microorganisms surrounded by secreted polymers responsible for many chronic infectious diseases as well as for contamination of clinical and industrial environments. The aim of this study was to assess the potential antimicrobial activity of zinc-, copperand silver-doped mullite ceramics disks against biofilm producing clinical isolates of Staphylococcus aureus, Staphylococcus epidermidis, Streptococcus mutans and Pseudomonas aeruginosa. It also aimed to compare their effect in preventing the initial bacterial adhesion and the accumulation and maturation of biofilm on the disk surfaces. The antibacterial activities of the metal-doped mullites against biofilm were found dependent on mineral concentration and the incubation time. Silver-mullite disks showed high potential for controlling early and late biofilms against the studied microorganisms. Copper-mullite disks had exerted better activity in reducing the $P$. aeruginosa adherence and biofilm growth as compared with the Gram positive bacteria. However, these disks failed to show antibacterial activity against $S$. mutans planktonic or biofilm grown after $24 \mathrm{~h}$ incubation. Interestingly, zinc-mullite disks enhanced the growth of $S$. aureus and S. epidermidis in suspension or biofilm.
\end{abstract}

Key words: Mullite ceramic, metal-doped mullite, bacterial adherence, biofilm.

\section{INTRODUCTION}

Microbial pollution of environment resources (such as water) and their role in the epidemiology of nosocomial infections have become a major threat to public health (Chen et al., 2012; Tao et al., 2011). This threat coincides with the appearance of multidrug resistant bacteria which are as well responsible for biofilm related infections. Among these common bacteria species are: $S$. aureus, S. epidermidis and P. aeruginosa (Martin and Yost, 2011; Morgan et al., 2012; Shanthi and Sekar, 2009; Singh et al., 2012).

Bacteria can adhere to surfaces or damaged tissues, encase themselves with slimy material (matrix or polymeric substance) and form what is called biofilm. Biofilms are associated with many medical conditions such as infections of indwelling implants, mainly by $S$. aureus and
S. epidermidis, dental plaques by $S$. mutans and the incurable cystic fibrosis by $P$. aeruginosa (Chifiriuc et al., 2011; Davies 2002; Roberts et al., 2002; Soto-Barreras et al., 2012). They cause serious compli-cations due to the chronic nature of these infections and the inherent multidrug resistance of the biofilm (Hurlow and Bowler, 2012). Most of the antibiotics available are with limited efficacy on their own to treat biofilm associated infections. With the increase of the frequency of biofilm related infections, investigators have consi-dered the search for alternative agents. Antibacterial properties of nano metal oxides such as silver and zinc oxides have been proposed as novel antimicrobial agents (Reddy at al., 2007; Lin et al., 1996). Metallic silver and silver salts have been used as bactericidal agents in silver-impregnated dressings for 
burn injuries (Kumar and Munstedt, 2005). Copper has been known for many years for its broad spectrum antimicrobial activity (Gosau et al., 2010; Heidenau et al., 2005), and it has been used for coating devices such as catheters and cannulas (Tang et al., 2007). As an extension of our research in this area (Saleh et al., 2011), we herein present an in vitro study to evaluate the bactericidal effect of copper-, silver- and zinc-doped mullite ceramics $\left(3 \mathrm{Al}_{2} \mathrm{O}_{3} \cdot 2 \mathrm{SiO}_{2}\right)$, and also to investigate their activity to avoid both bacterial colo-nization and biofilm formation.

The development of these antimicrobial surfaces is of great importance in maintaining acceptable levels of hygiene in hospitals and will help to limit the spread of nosocomial infections via the contamination of inanimate surfaces in the healthcare environment.

This study demonstrates the antimicrobial activities of mullite ceramics doped with different concentrations of the metals $\mathrm{Ag}, \mathrm{Cu}$, and $\mathrm{Zn}$ against biofilm producing strains of $S$. aureus, $S$. epidermidis, $S$. mutans and $P$. aeruginosa. The investigators aim for assessing the potential activities of metals in preventing the bacterial adhesion to the surfaces of the disks, and the durability of the activity in reducing the biofilm and the bactericidal or bacteriostatic effect against planktonic form of bacteria.

\section{MATERIALS AND METHODS}

\section{Materials}

Pure kaolin (Merck, Germany), aluminum oxide $\left(\gamma-\mathrm{Al}_{2} \mathrm{O}_{3}\right)$ (Fluka, Germany), carboxymethylcellulose (Fluka,Germany), sulfuric acid $\left(\mathrm{H}_{2} \mathrm{SO}_{4}\right)(\mathrm{BDH}, \mathrm{UK}), \mathrm{NH}_{3(\mathrm{aq})}$ (ammonia solution) (GCC, UK), copper(II) nitrate trihydrate $\left(\mathrm{Cu}\left(\mathrm{NO}_{3}\right)_{2} \cdot 3 \mathrm{H}_{2} \mathrm{O}\right)(\mathrm{BDH}$, UK), silver nitrate $\left(\mathrm{AgNO}_{3}\right)$ (Reidel de-Haen, Germany), zinc chloride $\left(\mathrm{ZnCl}_{2}\right)(\mathrm{GCC}, \mathrm{UK})$ were used for this study.

\section{Preparation of blank mullite disks}

Purified kaolin with particle size $\leq 75 \mu \mathrm{m}$ was calcined at $800^{\circ} \mathrm{C}$ for $8 \mathrm{~h}$ to transform it to amorphous metakaolin. A $23.0 \mathrm{~g}$ sample of metakaolin was mixed with $25.0 \mathrm{~g} \mathrm{r}-\mathrm{Al}_{2} \mathrm{O}_{3}, 2.0 \mathrm{~g}$ carboxymethylcellulose, and $75 \mathrm{ml}$ of $3 \mathrm{M} \mathrm{H}_{2} \mathrm{SO}_{4}$. The mixture was stirred in water bath at $80^{\circ} \mathrm{C}$ for $4 \mathrm{~h}$. The mixture was cooled to room temperature and then ammonia $(8 \% \mathrm{w} / \mathrm{w})$ was added till a $\mathrm{pH}=9.0$. The mixture was then filtered, washed with distilled water till the filtrate is sulfate free. The solid was dried at $110^{\circ} \mathrm{C}$ for $2 \mathrm{~h}$, and then ground in a ball mill at a speed of $400 \mathrm{rpm}$ for $1 \mathrm{~h}$ to give the mullite precursor powder.

For the preparation of blank disks, the powder was mixed with enough water to form a paste which was then pressed in a metal mold to form disks (diameter: $\sim 20 \mathrm{~mm}$, thickness: $\sim 3 \mathrm{~mm}$ ). The disks were dried at $110^{\circ} \mathrm{C}$ for $2 \mathrm{~h}$ and then heated at $900^{\circ} \mathrm{C}$ for $6 \mathrm{~h}$ and finally sintered at $1450^{\circ} \mathrm{C}$ for $6 \mathrm{~h}$. These disks were coded as B-mullite.

\section{Preparation of metal-doped mullite disks}

A $10.0 \mathrm{~g}$ sample of the mullite precursor powder was soaked in 50 $\mathrm{ml}$ of $1.0 \mathrm{M}, 1.5 \mathrm{M}$, or $2.0 \mathrm{M}$ solution of the metal salt, and the mix- ture was stirred for $1 \mathrm{~h}$ at $60^{\circ} \mathrm{C}$. The metal impregnated solid was filtered and dried at $110^{\circ} \mathrm{C}$. Disks were made and heat- treated as outlined in the preparation of the blank disks above. Metal salts used are $\mathrm{Cu}\left(\mathrm{NO}_{3}\right)_{2} \cdot 3 \mathrm{H}_{2} \mathrm{O}, \mathrm{AgNO}_{3}$, and $\mathrm{ZnCl}_{2}$. Silver solutions, mixtures containing silver ions, and $\mathrm{Ag}$-doped disks were protected from light. The disks were coded according to the metal salt used and its concentrations as: $\mathrm{Cu}(1.0)$-mullite, $\mathrm{Cu}(1.5)$-mullite, $\mathrm{Cu}(2.0)$ mullite; $\mathrm{Ag}(1.0)$-mullite, $\mathrm{Ag}(1.5)$-mullite, $\mathrm{Ag}(2.0)$-mullite; $\mathrm{Zn}(1.0)$ mullite, $\mathrm{Zn}(1.5)$-mullite, $\mathrm{Zn}(2.0)$-mullite.

\section{Characterization of the mullite ceramics}

\section{$X$-ray diffraction (XRD)}

The powder $\mathrm{X}$-ray diffraction spectra were measured using a SHIMADZU model XRD-6000 with nickel filtered and copper X-ray radiation (CuKa, $\lambda=1.5406 \AA$ ). Scanning was done continuously with a speed of $2.000(\mathrm{deg} / \mathrm{min})$.

\section{Elemental analyses}

The chemical composition of samples was done using X-ray fluorescence spectrometer SHIMADZU model XRF-1800.

\section{Bacterial strains and culture conditions}

Clinical isolates of $S$. epidermidis (catheter infection), $S$. aureus (wound infection), S. mutans (dental plaque) and $P$. aeruginosa (nosocomial infection) were investigated in this study. The bacterial strains that are biofilm producers were tested for biofilm production by microtiter plate biofilm production assay (Croes et al., 2009) where applicable, bacterial strains were grown on Mueller-Hinton broth (MHB) (Oxoid) or agar (MHA) (Oxoid) throughout the experiments and incubated at $37^{\circ} \mathrm{C}$ under aerobic conditions. $S$. mutans, when needed, were inoculated on MHA or MHB supplemented with $5 \%$ sheep blood (Oxoid). Prior to experiments, bacterial strains were grown in MHB overnight at $37^{\circ} \mathrm{C}$ and the cultures were adjusted to $0.5 \mathrm{McF}$ Farland and diluted with phosphate buffer saline (PBS) to the acquired working concentration of $10^{6}$ $\mathrm{CFU} / \mathrm{ml}$. Inoculum preparations were carried out in accordance to guidelines recommended by the Clinical and Laboratory Standards Institute (CLSI; formerly NCCLS).

\section{Antimicrobial activity test methods}

\section{Agar diffusion method}

Agar diffusion method was used for evaluating the antibacterial activity of $\mathrm{AgNO}_{3}, \mathrm{Cu}\left(\mathrm{NO}_{3}\right)_{2}$, and $\mathrm{ZnCl}_{2}$ salts. Wells of about $6 \mathrm{~mm}$ diameter were made aseptically using gel puncture instrument into MHA plates. The plates were swabbed with different microorganism equivalent to $0.5 \mathrm{McF}$ arland standard. The wells were filled with 50 $\mu \mathrm{l}$ of each chemical at concentration of $0.1 \mathrm{~g} / \mathrm{ml}$. The plates were incubated at $37^{\circ} \mathrm{C}$ for $24 \mathrm{~h}$. Antibacterial activity was evaluated by measuring the diameter of the zone of inhibition around each well.

\section{Disk diffusion test}

The disk diffusion test is only qualitative and easy to perform and has the aim to determine the antibacterial activity of diffusible antimicrobial agents in the treated disks. Bacterial suspensions were adjusted to $0.5 \mathrm{McF}$ arland standard and spread onto MHA plates. Metal-doped mullite disks were placed on MHA. Plates were 
Table 1. Elemental analysis of blank mullite (B-mullite).

\begin{tabular}{llllllllll}
\hline Analyte & $\mathrm{Al}_{2} \mathrm{O}_{3}$ & $\mathrm{SiO}_{2}$ & $\mathrm{Fe}_{2} \mathrm{O}_{3}$ & $\mathrm{~K}_{2} \mathrm{O}$ & $\mathrm{CaO}$ & $\mathrm{P}_{2} \mathrm{O}_{5}$ & $\mathrm{Ag}_{2} \mathrm{O}$ & $\mathrm{TiO}_{2}$ & $\mathrm{CuO}$ \\
\hline Result (\%) & 72.49 & 26.78 & 0.22 & 0.27 & 0.086 & 0.046 & 0.040 & 0.027 & 0.0091 \\
\hline
\end{tabular}

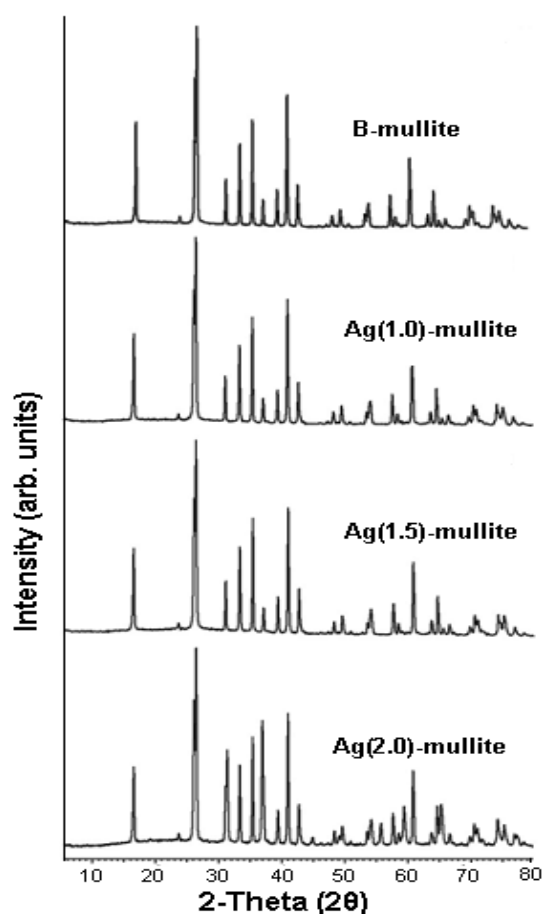

Figure 1. XRD spectra of synthesized mullite (a) B-mullite, (b) $\mathrm{Ag}(1.0)$-mullite, (c) $\mathrm{Ag}$ (1.5)-mullite and (d) $\mathrm{Ag}(2.0)$-mullite.

incubated for $24 \mathrm{~h}$ at $37^{\circ} \mathrm{C}$ and inhibition zones around the disks were measured.

\section{Bacteriostatic and bactericidal effect of minerals (MIC and MBC of planktonic form of bacteria)}

Microtiter minimal inhibition concentration (MIC) and minimal bactericidal concentration (MBC) tests were done according to CLSI (formerly NCCLS) guidelines in 96-well tissue culture plates. Serial twofold dilutions of the chemicals ranging from $0.01-0.00005 \mathrm{~g} / \mathrm{ml}$ were performed in Mueller-Hinton broth. A suspension of the organism was added to wells at a concentration of $5 \times 10^{5} \mathrm{CFU} / \mathrm{ml}$, and the microtiter plates were incubated at $37^{\circ} \mathrm{C}$ for $24 \mathrm{~h}$. The MIC was read optically as the lowest concentration of mineral in which there was no visible growth after overnight incubation. In wells where there was no visible growth, $10 \mu \mathrm{l}$ was subcultured to MHA and were incubated at $37^{\circ} \mathrm{C}$ for colony count. MBC was read as the highest dilution showing $\sim 99.9 \%$ kill after $24 \mathrm{~h}$ of incubation.

\section{MIC and MBC of biofilm forming bacteria (BMIC and BMBC)}

BMIC and BMBC were done as previously described (Ceri et al., 1999; Aaron et al., 2000). All bacterial species were first grown as biofilms. Biofilms were produced via suspension of each bacterial species in MHB to a 0.5 McFarland standard, and $100 \mu \mathrm{l}$ was added to wells of a 96-well round-bottomed microtiter plate (NUNC). A transferable solid-phase (TSP) pin lid (NUNC) was placed into the microtiter plate and incubated overnight at $37^{\circ} \mathrm{C}$ on a see-saw rocker to produce a shear force. The TSP pin lid was then removed and placed into a new microtiter plate containing the twofold dilutions of the chemical incubated for $24 \mathrm{~h}$ at $37^{\circ} \mathrm{C}$ on the rocker platform. The MIC was read as the last well in which there was no visible growth. The TSP pin lid was then transferred to a 96-well microtiter plate containing sterile MHB and sonicated for $5 \mathrm{~min}$ in ultra bath sonicator. The TSP pin lid was discarded and replaced by a sterile microtiter lid, and the plate was incubated for $24 \mathrm{~h}$ at $37^{\circ} \mathrm{C}$. The $\mathrm{MBC}$ was determined as the last well showing no turbidity after overnight incubation.

\section{Analysis of planktonic growth in the presence of metal-doped} mullite ceramic disks

Modified shake flask test was used to study the effect of the disks on planktonic bacterial growth after 1 and $24 \mathrm{~h}$ incubation (Yan et al., 2002). Two 50-ml- falcon centrifuge tubes were used instead of flasks. One tube was used after one hour incubation and the other after $24 \mathrm{~h}$ incubation. The absorbance at $600 \mathrm{~nm}$ of all bacterial suspensions was adjusted to 0.05 prior to preparing inoculum. Bacterial suspensions were adjusted to $1.0-2.5 \times 10^{6} \mathrm{CFU} / \mathrm{ml}$ in $1 / 10$ strength broth $(25 \mathrm{ml} /$ tube). In each tube a single disk was placed and the tubes were shaken at $300 \mathrm{rpm}$ and $37^{\circ} \mathrm{C}$. Blank disks were included in the experiments as controls. Aliquots after one hour and $24 \mathrm{~h}$ were serially diluted in phosphate buffer saline (PBS) for viable bacterial counting by pour plate method. Disks were removed to measure their anti-adherence (after one hour incubation) and anti-biofilm (after $24 \mathrm{~h}$ incubation) activities (see the next section).

\section{Biofilm formation and measuring anti-adherence activity of the disks}

Bacterial attachment to disk surface was measured as previously described with slight modifications (Overhage et al., 2008). Disks after one hour and $24 \mathrm{~h}$ incubation were removed (see the previous section) and washed gently three times in successive $25 \mathrm{ml}$ PBS to remove loosely attached bacteria. Each disk was placed in 6 well tissue culture plate containing $5 \mathrm{ml}$ PBS and sonicated for $5 \mathrm{~min}$ at $100 \%$ intensity. Aliquots were serially diluted in PBS for viable bacterial counting by pour plate method. The plates were incubated at $37^{\circ} \mathrm{C}$ overnight. Blank disks were used as controls in the experiments.

\section{RESULTS}

\section{Mullite ceramic disks}

The formation of the mullite phase in the mullite ceramic disks was confirmed by elemental analysis (Table 1) and XRD-spectrum (Figure 1A). XRD-spectra of mullite doped with different concentrations of $\mathrm{Ag}$ are shown in Figure $1 \mathrm{~B}, \mathrm{C}$ and $\mathrm{D}$. 
Table 2. Zone of inhibition against the tested bacteria*

\begin{tabular}{lcccc}
\hline \multirow{2}{*}{ Parameter } & S. epidermidis & S. aureus & S. mutans & P. aeruginosa \\
\cline { 2 - 5 } & & \multicolumn{3}{c}{ Zone of inhibition $(\mathbf{m m})^{\star *}$} \\
\hline $\mathrm{AgNO}_{3}$ & 19.0 & 18.0 & 19.0 & 18.0 \\
$\mathrm{Cu}\left(\mathrm{NO}_{3}\right)_{2}$ & 20.0 & 21.5 & 21.0 & 17.0 \\
$\mathrm{ZnCl}$ & 13.5 & 15.0 & 15.0 & 13.5 \\
\hline
\end{tabular}

*Salt concentration is $0.1 \mathrm{~g} / \mathrm{ml}$.

${ }^{* *}$ The zone of inhibition by gentamicin (10 $\mu \mathrm{g}$ in disc) against $P$. aeruginosa is $\geq 15 \mathrm{~mm}$, $S$. aureus $\geq 18 \mathrm{~mm}, S$. epidermidis $\geq 22 \mathrm{~mm}$ and $S$. mutans is not applicable.

Table 3. Inhibition zone on the periphery of the metal-doped mullite disks against the tested bacteria.

\begin{tabular}{|c|c|c|c|c|}
\hline \multirow{2}{*}{ Parameter } & S. epidermidis & S. aureus & S. mutans & P. aeruginosa \\
\hline & \multicolumn{4}{|c|}{ Zone of inhibition $(\mathrm{mm})$ on the periphery of the disk } \\
\hline $\mathrm{Ag}(2.0)$-mullite & 2.0 & 2.0 & 2.0 & 3.0 \\
\hline $\mathrm{Ag}(1.5)$-mullite & 1.5 & 1.0 & 0.5 & 2.0 \\
\hline $\mathrm{Ag}(1.0)$-mullite & 1.0 & 0.5 & $\mathrm{NI}$ & 0.5 \\
\hline $\mathrm{Cu}(2.0)$-mullite & $\mathrm{NI}^{*}$ & $\mathrm{NI}$ & $\mathrm{NI}$ & $\mathrm{NI}$ \\
\hline $\mathrm{Cu}(1.5)$-mullite & $\mathrm{NI}$ & $\mathrm{NI}$ & $\mathrm{NI}$ & $\mathrm{NI}$ \\
\hline $\mathrm{Cu}(1.0)$-mullite & $\mathrm{NI}$ & $\mathrm{NI}$ & $\mathrm{NI}$ & $\mathrm{NI}$ \\
\hline $\mathrm{Zn}(2.0)$-mullite & $\mathrm{NI}$ & $\mathrm{NI}$ & $\mathrm{NI}$ & $\mathrm{NI}$ \\
\hline $\mathrm{Zn}(1.5)$-mullite & $\mathrm{NI}$ & $\mathrm{NI}$ & $\mathrm{NI}$ & $\mathrm{NI}$ \\
\hline $\mathrm{Zn}(1.0)$-mullite & $\mathrm{NI}$ & $\mathrm{NI}$ & $\mathrm{NI}$ & $\mathrm{NI}$ \\
\hline
\end{tabular}

\section{Agar diffusion test}

The antibacterial effect of water solutions of the metal ions was investigated by the agar diffusion test. The inhibition zone results (Table 2 ) are the average value of three experiments. The zones were measured using a ruler with $1 \mathrm{~mm}$ resolution so the possibility of measurement error exists. $\mathrm{Cu}\left(\mathrm{NO}_{3}\right)_{2}$ showed the highest inhibition zones $\sim 20 \mathrm{~mm}$, while $\mathrm{AgNO}_{3}$ and $\mathrm{ZnCl}_{2}$ showed 18.5 and $14.3 \mathrm{~mm}$, respectively.

\section{Disk diffusion test}

The antibacterial effect of the metal-doped mullite disks was investigated by the disk diffusion test. The inhibition zone around the disks was measured. The results shown in Table 3 are the average value of three experiments. The results suggest that Ag-mullite disks were active against all the tested organisms. Ag-mullite disks showed higher inhibition segments against $P$. aeruginosa than all the other Gram positive organisms tested in this study. The $A g(2.0)$-mullite showed the largest zone of inhibition. However, $\mathrm{Zn}$ - and Cu-mullites disks did not show any inhibition zones except the activity of Cu-mullite disks against $S$. mutans. Furthermore, decreased num- ber of colonies was observed at the bottom of all disks except for the Ag-mullite disks that show no colo-nies at all. Blank disks were tested along side by side with metal-mullite disks.

\section{Planktonic MIC and MBC of minerals against bacterial strains}

The antibacterial activity as MIC and MBC were assessed for the metal salts against planktonic bacterial using the microtiter 96 well plates. The MIC/MBC results in Table 4 observed for $\mathrm{AgNO}_{3}$ were in a range of 0.01 $0.05 / 0.05-0.09 \mathrm{mg} / \mathrm{ml}$ suggesting that the organisms are more sensitive to $\mathrm{AgNO}_{3}$ than to $\mathrm{Cu}\left(\mathrm{NO}_{3}\right)_{2}$ and $\mathrm{ZnCl}_{2}$.

\section{MIC and MBC of metal salts against biofilm forming bacteria}

The bacteriostatic and bactericidal effect of the metal salts against bacterial strains grown in biofilms was obtained. The results are shown in Table 5. MIC and MBC results of $\mathrm{AgNO}_{3}$ showed increased activity against Gram positive when compared to Gram negative biofilm producing $P$. aeruginosa. However, $\mathrm{ZnCl}_{2} \mathrm{MIC}$ and $\mathrm{MBC}$ 
Table 4. Minimum inhibitory and minimum bactericidal concentrations (MIC and MBC) of silver, copper and zinc lons against planktonic bacteria.

\begin{tabular}{|c|c|c|c|c|}
\hline & S. epidermidis & S. aureus & S. mutans & P. aeruginosa \\
\hline Parameter & $\begin{array}{c}\mathrm{MIC} / \mathrm{MBC}^{*} \\
\mathrm{mg} / \mathrm{ml}\end{array}$ & $\begin{array}{c}\mathrm{MIC} / \mathrm{MBC} \\
\mathrm{mg} / \mathrm{ml}\end{array}$ & $\begin{array}{c}\mathrm{MIC} / \mathrm{MBC} \\
\mathrm{mg} / \mathrm{ml}\end{array}$ & $\begin{array}{c}\mathrm{MIC} / \mathrm{MBC} \\
\mathrm{mg} / \mathrm{ml}\end{array}$ \\
\hline $\mathrm{AgNO}_{3}$ & $0.05 / 0.07$ & $0.05 / 0.09$ & $0.05 / 0.06$ & $0.01 / 0.05$ \\
\hline $\mathrm{Cu}\left(\mathrm{NO}_{3}\right)_{2}$ & $0.12 / 0.30$ & $0.12 / 0.30$ & $0.12 / 0.30$ & $0.30 / 0.60$ \\
\hline $\mathrm{ZnCl}_{2}$ & $0.40 / 0.70$ & $0.40 / 0.70$ & $0.40 / 0.70$ & $0.30 / 0.50$ \\
\hline
\end{tabular}

${ }^{*}$ The results are the average of at least three determinations.

Table 5. Minimum inhibitory and minimum bactericidal concentrations (MIC and MBC) of silver, copper and zinc salts against biofilm.

\begin{tabular}{lcccc}
\hline \multirow{2}{*}{ Parameter } & S. epidermidis & S. aureus & S. mutans & P. aeruginosa \\
\cline { 2 - 4 } & \multicolumn{4}{c}{$\mathbf{M I C} / \mathbf{M B C}^{*}$} \\
& $>0.05 / 0.10$ & $>0.05 / 0.10$ & $>0.05 / 0.10$ & $0.50 />0.50$ \\
$\mathrm{AgNO}_{3}$ & $0.80 />1.5$ & $0.40 / 0.80$ & $0.80 />1.2$ & $1.2 / 3.0$ \\
$\mathrm{Cu}\left(\mathrm{NO}_{3}\right)_{2}$ & $1.0 />1.0$ & $1.5 />1.5$ & $1.5 />1.5$ & $>0.70 / 1.0$ \\
$\mathrm{ZnCl}$ &
\end{tabular}

${ }^{*}$ The results are the average of at least three determinations.

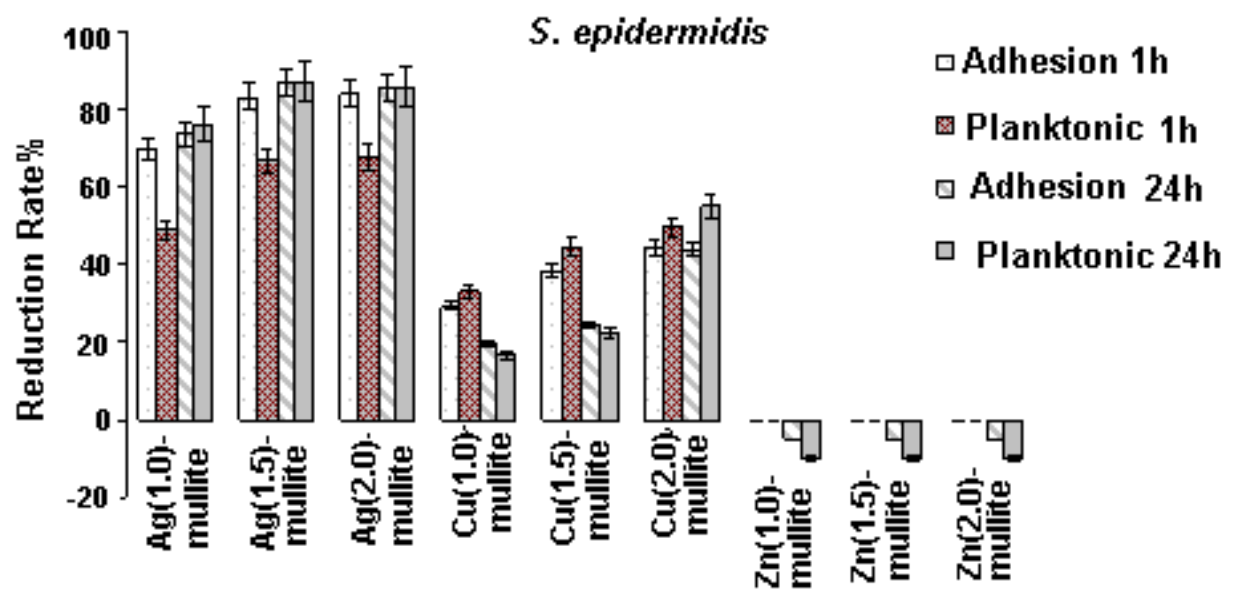

Figure 2. The anti-adherence and anti-biofilm formation activity and the effect on planktonic growth of metal-doped disks with different concentrations of $\mathrm{AgNO}_{3}, \mathrm{Cu}\left(\mathrm{NO}_{3}\right)_{2}$, and $\mathrm{ZnCl}_{2}$ against $S$. epidermidis.

values were observed with increased activity against $P$. aeruginosa when compared to biofilm forming Gram positive bacterial strains. Furthermore, MIC and MBC of $\mathrm{Cu}\left(\mathrm{NO}_{3}\right)_{2}$ showed better activity than $\mathrm{ZnCl}_{2}$ against Gram positive organisms but less active against $P$. aeruginosa.

\section{Measuring anti-adherence, anti-biofilm formation and analysis of planktonic growth of biofilm producers pathogens in the presence of metal-doped mullite disks}

The antimicrobial activity of the disks took another dimen- sion in testing the efficacy of the metal-doped mullite disks to prevent or minimize the bacterial attachment to the surfaces.

The experiment was extended to test the efficiency of the metal-doped disks in preventing or decreasing the biofilm forming on the disk surface. Bacterial adhesion to the surfaces of uncoated disks was obtained after one hour incubation to test the microbial adherence and after $24 \mathrm{~h}$ to test the biofilm formation.

Results shown in Figures 2, 3, 4 and 5 represent the average value of three experiments. The numbers of CFU for all tested organisms were obtained by serial dilution method. The reduction rate was estimated based 


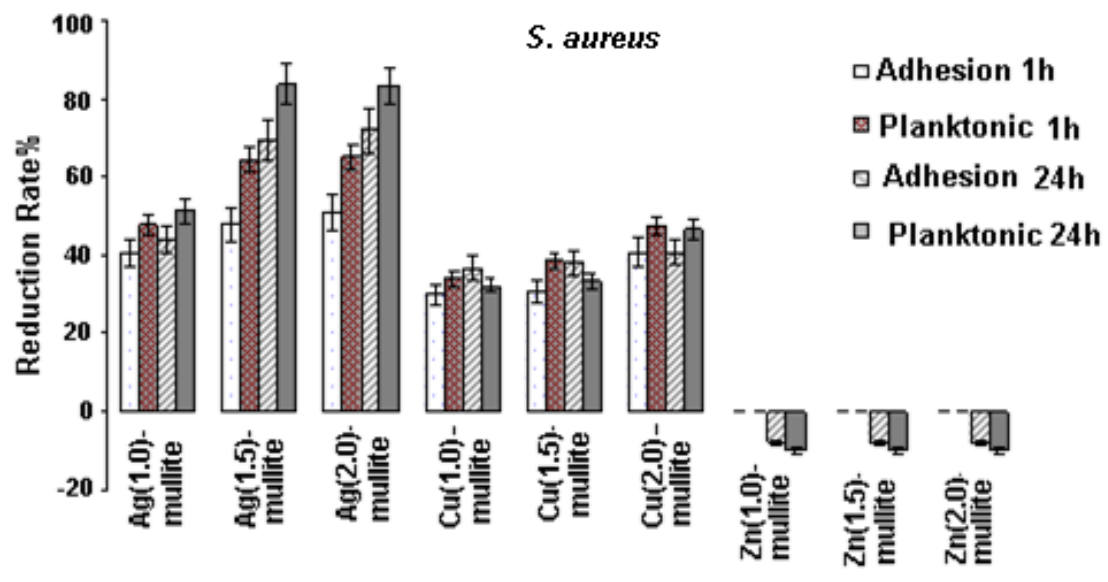

Figure 3. The anti-adherence and anti-biofilm formation activity and the effect on planktonic growth of metal-doped disks with different concentrations of $\mathrm{AgNO}_{3}$, $\mathrm{Cu}\left(\mathrm{NO}_{3}\right)_{2}$, and $\mathrm{ZnCl}_{2}$ against $S$. aureus.

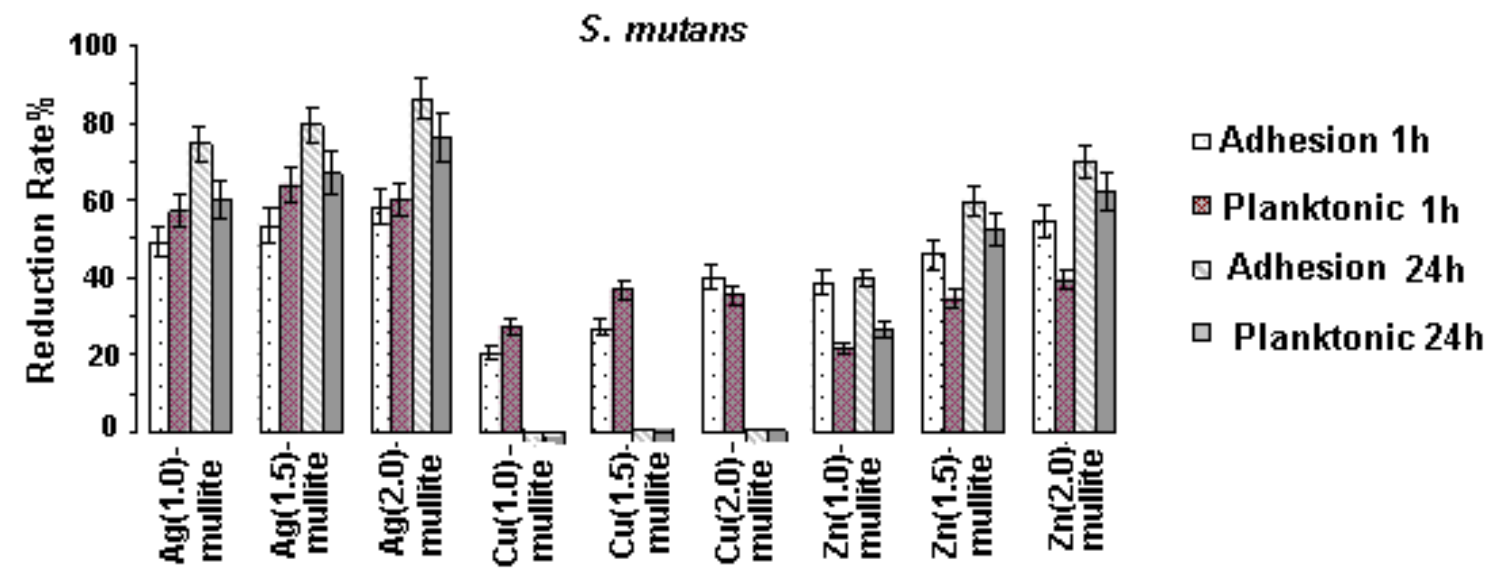

Figure 4. The anti-adherence and anti-biofilm formation activity and the effect on planktonic growth of metaldoped disks with different concentrations of $\mathrm{AgNO}_{3}, \mathrm{Cu}\left(\mathrm{NO}_{3}\right)_{2}$, and $\mathrm{ZnCl}_{2}$ against $S$. mutans.

on the following equation:

\section{Reduction rate $\%=[($ Blank CFU-Tested CFU $) /$ Blank CFU] $\times 100 \%$.}

The antibacterial activity for the metal-doped mullite disks against $S$. epidermidis is shown in Figure 2 . The increase in the concentration of $\mathrm{Ag}$ in the disks lowers bacterial adherence after one hour incubation and affected the planktonic bacteria as well. The activity extended for $24 \mathrm{~h}$ in decreasing biofilm growth. $\mathrm{Ag}(1.5)$ mullite and $\mathrm{Ag}(2.0)$-mullite had a reduction rate of $\sim 90 \%$ in biofilm growth and planktonic bacteria. By comparison, Cu-doped mullite disks had a reducing rate of $20-40 \%$. Interestingly, Zn-doped mullite disks enhanced $S$. epidermidis growth in suspension and biofilm by $5 \%$ in the first hour of incubation and $8 \%$ in the $24 \mathrm{~h}$.
Assessing the antibacterial activity of Ag-doped mullite disks against $S$. aureus did not show a significant difference when compared to $S$. epidermidis after $24 \mathrm{~h}$ incubation with $90 \%$ reduction rate in biofilm growth. However, Zn-doped mullite disks did not exerted any activity against $S$. aureus but instead they promoted the growth of bacterial suspensions as well as biofilm development by $8 \%$ in the first hour and $10 \%$ in $24 \mathrm{~h}$. Results are shown in Figure 3.

Results shown in Figure 4 continued to suggest that Ag-doped mullite disks have a potential activity against $S$. mutans and on all the three stages of biofilm formation: bacterial adhesion, accumulation and maturation in Gram positive bacteria. $\mathrm{Ag}(2.0)$-mullite disks showed reduction rate of $90 \%$ after $24 \mathrm{~h}$ on biofilm growth and $70 \%$ on planktonic bacteria. The bactericidal effect of silver in the previous manner supports its benefit use in periodontal 


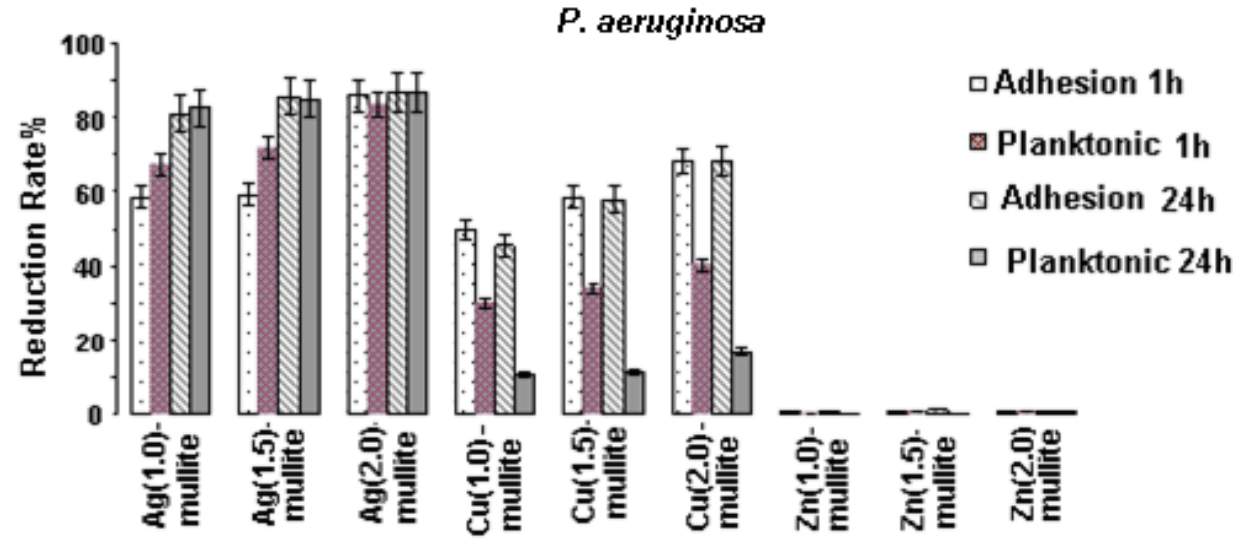

Figure 5. The anti-adherence and anti-biofilm formation activity and the effect on planktonic growth of metal-doped disks with different concentrations of $\mathrm{AgNO}_{3}, \mathrm{Cu}\left(\mathrm{NO}_{3}\right)_{2}$, and $\mathrm{ZnCl}_{2}$ against $P$. aeruginosa.

diseases and tooth fillings.

Activity of Cu-doped mullite disks was influenced by the time of incubation. After $1 \mathrm{~h}$ incubation the disks ( $\mathrm{Cu}(1.0)-, \mathrm{Cu}(1.5)-$, and $\mathrm{Cu}(2.0)$-mullite disks) had a reduction rate of 20,35 and $40 \%$, respectively. However, the copper disks did not have any activity against biofilm formation after $24 \mathrm{~h}$; on the contrary, it enhanced signifycantly the growth of planktonic $S$. mutans when compared to blank disks tested by student $t$-test $(P<0.01)$.

Results of the antibacterial activity against $P$. aeruginosa for silver-, copper- and zinc-doped disks are shown in Figure 5. Again Ag-doped disks had a potential bactericidal effect against planktonic and biofilm grown $P$. aeruginosa. Cu-doped disks activity against the planktonic bacteria did not exceed the $15 \%$ reduction rate after $24 \mathrm{~h}$ incubation but it was active against the adherent and biofilm grown $P$. aeruginosa with $65 \%$ reduction rate. Neither planktonic nor biofilm grown $P$. aeruginosa were affected by Zinc-doped disks after 1 or $24 \mathrm{~h}$ incubation.

\section{DISCUSSION}

Pure mullite phase was prepared and characterized by elemental analysis (Table 1) and XRD-spectra (Figure 1). Doping of the mullite with the metal ions $\mathrm{Ag}^{+}, \mathrm{Zn}^{2+}$, and $\mathrm{Cu}^{2+}$ slightly affects the results of the elemental analysis as compared with the blank, but has no significant effect on the crystalline structure of the mullite. It is highly believed that $\mathrm{Zn}^{2+}$ and $\mathrm{Cu}^{2+}$ share silicon and aluminum in the buildup of the mullite framework (Sarin et al., 2008), whereas, $\mathrm{Ag}^{+}$is included within the mullite framework.

This study demonstrates the antimicrobial activities of mullite ceramics doped with different concentrations of the metals $\mathrm{Ag}, \mathrm{Cu}$, and $\mathrm{Zn}$ against biofilm producing strains of $S$. aureus, $S$. epidermidis, $S$. mutans and $P$. aeruginosa. The investigators aim for assessing the potential activities of metals in preventing the bacterial adherence to the surfaces of the disks, and the durability of the activity in reducing the biofilm and the bactericidal or bacteriostatic action against planktonic bacteria.

The experiments were designed to compare between the activity of the zinc, copper and silver salts used as powders and the activity of these salts after being incorporated in the mullite phase during its formation. Results of agar diffusion susceptibility tests showed that $\mathrm{Cu}\left(\mathrm{NO}_{3}\right)_{2} \quad(0.10 \mathrm{~g} / \mathrm{ml})$ had better antimicrobial activity against $S$. aureus, $S$. mutans and $P$. aeruginosa strains when compared to $\mathrm{ZnCl}_{2}$ and $\mathrm{AgNO}_{3}$. However, disks diffusion tests indicated that only Ag-doped disks exerted antimicrobial activity against the tested bacteria. This might be due to the fact that inhibition zones can only be created by diffusion of antimicrobial material and only the Ag composites demonstrated inhibition zones due to the diffusion of $\mathrm{Ag}^{+}$.

The MIC/MBC values for $\mathrm{AgNO}_{3}, \mathrm{Cu}\left(\mathrm{NO}_{3}\right)_{2}$ and $\mathrm{ZnCl}_{2}$ against planktonic and biofilm grown bacteria showed strain specificity among Gram positive and Gram negative bacteria. Values were consistent with microorganisms that were most sensitive to $\mathrm{AgNO}_{3}(0.05 / 0.07$ $\mathrm{mg} / \mathrm{ml})$ and least to $\mathrm{ZnCl}_{2}(0.40 / 0.70 \mathrm{mg} / \mathrm{ml})$ with a minimum one fold increase in MIC/MBC values for Gram positive bacteria grown as biofilms. Furthermore, MIC/$\mathrm{MBC}$ for $P$. aeruginosa (planktonic) was found to be more sensitive to $\mathrm{AgNO}_{3}(0.01 / 0.05 \mathrm{mg} / \mathrm{ml})$ but more resistant to $\mathrm{Cu}\left(\mathrm{NO}_{3}\right)_{2}(0.30 / 0.60 \mathrm{mg} / \mathrm{ml})$ when compared to Gram positive $(0.12 / 0.30 \mathrm{mg} / \mathrm{ml})$. Interestingly for $P$. aeruginosa grown as biofilm, the $\mathrm{MIC} / \mathrm{MBC}$ value for $\mathrm{AgNO}_{3}$ was found to be $(0.50 />0.50 \mathrm{mg} / \mathrm{ml})$ that would mean $P$. aeruginosa is more resistant to $\mathrm{AgNO}_{3}$ than Gram positive bacteria when grown as biofilm. Finally, $\mathrm{ZnCl}_{2}$ has greater bacteriostatic and bactericidal effect against $P$. aeruginosa grown as planktonic and biofilm when compared to Gram positive bacteria. The antimicrobial property of the metal-doped mullite ceramics against the adherence and colonization of the bacteria were studied. 
The initial bacterial concentration was almost constant $5 \times 10^{5} \mathrm{CFU} / \mathrm{ml}$ irrespective of the metal concentration in the metal-doped disks or the microbial strain. Ag-doped disks showed anti-adherence and anti-colonization in proportion to increase in metal concentration against all studied microorganisms after 1 and $24 \mathrm{~h}$ incubation.

Bacteria strains studied were more tolerant to Agdoped mullite within $1 \mathrm{~h}$ incubation. The effect was better in $24 \mathrm{~h}$ incubation. This might be due to the diffusion ability of the silver ions into the suspension and the durability of its antimicrobial activity against microorganisms.

The activity of Cu-doped mullite and $\mathrm{Zn}$-doped mullite as anti-adherence and anti-colonization agents were found to be strain specific. Cu-mullite showed better activity within $1 \mathrm{~h}$ incubation against $S$. epidermidis, $S$. mutans and $P$. aeruginosa, however discrepancies were found after $24 \mathrm{~h}$ incubation. $\mathrm{Cu}(2.0)$-mullite disks decreased the adherence of $P$. aeruginosa after $1 \mathrm{~h}$ and $24 \mathrm{~h}$ incubation with reduction rate of $70 \%$ but of an average of about $22 \%$ reduction rate in suspended bacteria. These results indicate the potential of Cu-mullite as anti-adherence agent against $P$. aeruginosa. However, the growth of $\mathrm{S}$. mutans was enhanced after $24 \mathrm{~h}$ incubation with all Cu-mullite disks ( $\mathrm{Cu}(1.0)-, \mathrm{Cu}(1.5)$-, and $\mathrm{Cu}(2.0)$-mullite). This result highlights the fact that Cu-mullite disks activity depends on the duration of exposing the bacteria to the disks. Harrison et al. (2008) elaborated that bacterial biofilms are affected by the duration of exposing the metals to biofilms rendering them to active agents against biofilm after certain time of incubation.

Bacterial sensitivity to Zn-doped mullite disks was found to vary depending on the microbial species. $S$. mutans adherence was affected with different concentration of zinc in Zn-mullite disks, after 1 and $24 \mathrm{~h}$ incubation. However, these disks showed less effect on the planktonic bacteria. While on the other hand, $\mathrm{Zn}$ doped mullite disks failed to stop the attachment and the maturation of $P$. aeruginosa biofilms similarly as it was found by Saleh et al. (2011). In accordance with a study by Conrady et al. (2008), it was found that $\mathrm{Zn}$-mullite disks enhanced the growth of both $S$. aureus and $S$. epidermidis excluding the substance as a potential antiadherence and anti colonization agent against staphylococcal strains.

\section{Conclusions}

This study shows that silver-doped mullite ceramics have great promise as antimicrobial agent against $S$. aureus, $S$. epidermidis, $S$. mutans and $P$. aeruginosa grown as biofilms. However, for in vivo use, silver doped mullite requires extensive investigation to explore the toxicity to humans. The study showed that long exposure of $S$. mutans to Cu-doped mullite disks resulted in enhanced bacterial growths that was also found in exposing $S$. aureus and $S$. epidermidis to $\mathrm{ZnCl}_{2}$. For better understanding of the way in which these microorganisms interact in situ on metal-doped mullite ceramics, scanning electron microscopy for biofilm monitoring should be considered in close future.

Although the mechanism of action for these metals has not been revealed in this study; results might suggest that metals $(\mathrm{Zn}, \mathrm{Cu}$ and $\mathrm{Ag}$ ) could influence the operon activity responsible for biofilm formation, or simply it has a bacteriostatic or bactericidal effect on bacterial growth.

\section{ACKNOWLEDGEMENTS}

The financial support of Hamdi Mango Center for Scientific Research/ The University of Jordan is highly appreciated.

\section{REFERENCES}

Aaron SD, Ferris W, Henry DA, Speert DP, Macdonald NE (2000). Multiple combination bactericidal antibiotic testing for patients with cystic fibrosis infected with Burkholderia cepacia. Am. J. Respir. Crit. Care Med. 161:1206-1212.

Ceri H, Olson ME, Stremick C, Read RR, Morck D, Buret A (1999). The Calgary Biofilm Device: new technology for rapid determination of antibiotic susceptibilities of bacterial biofilms. J. Clin. Microbiol. 37:177-176.

Chen R, Yan ZQ, Feng D, Luo YP, Wang LL, Shen DX (2012). Nosocomial bloodstream infection in patients caused by Staphylococcus aureus: drug susceptibility, outcome, and risk factors for hospital mortality. Chin. Med. J. 125:226-229.

Chifiriuc MC, Banu O, Bleotu C, Lazar V (2011). Interaction of bacteria isolated from clinical biofilms with cardiovascular prosthetic devices and eukaryotic cells. Anaerobe 17:419-421.

Conrady DG, Brescia CC, Horii K, Weiss AA, Hassett DJ, Herr AB (2008). A zinc-dependent adhesion module is responsible for intercellular adhesion in staphylococcal biofilms. Proc. Nat. Acad. Sci. U.S.A. 105:19456-19461.

Croes S, Deurenberg RH, Boumans ML, Beisser PS, Neef C, Stobberingh EE (2009). Staphylococcus aureus biofilm formation at the physiologic glucose concentration depends on the $S$. aureus lineage. BMC Microbiol. 9:229.

Davies JC (2002). Pseudomonas aeruginosa in cystic fibrosis: pathogenesis and persistence. Paediatr Respir Rev. 3:128-134.

Gosau M, Prantl L, Feldmann M, Kokott A, Hahnel S, Bürgers R. (2010). The effects of copper additives on the quantity and cell viability of adherent Staphylococcus epidermidis in silicone implants. Biofouling 26:359-365.

Harrison JJ, Turner RJ, Ceri H (2005). Persister cells, the biofilm matrix and tolerance to metal cations in biofilm and planktonic Pseudomonas aeruginosa. Environ. Microb. 7:981-994.

Heidenau F, Mittelmeier W, Detsch R, Haenle M, Stenzel F, Ziegler G, Gollwitzer $H$ (2005). A novel antibacterial titania coating: metal ion toxicity and in vitro surface colonization. J. Mater. Sci. Mater. Med. 16:883-888.

Hurlow J, Bowler PG (2012). Potential implications of biofilm in chronic wounds: a case series. J. Wound Care 21:109-10,112, 114 passim.

Kumar R, Munstedt H (2005). Silver ion release from antimicrobial polyamide/silver composites. Biomaterials 26:2081-2088.

Lin YE, Vidic RD, Stout JE, Yu VL (1996). Individual and combined effects of copper and silver ions on inactivation of Legionella pneumophila. Water Res. 30:1905-1913.

Martin SJ, Yost RJ (2011). Infectious diseases in the critically ill patients. J. Pharm. Pract. 24:35-43.

Morgan DJ, Rogawski E, Thom KA, Johnson JK, Perencevich EN, 
Shardell M, Leekha S, Harris AD (2012). Transfer of multidrugresistant bacteria to healthcare workers' gloves and gowns after patient contact increases with environmental contamination. Crit. Care Med. 40:1045-1051.

National Committee for Clinical Laboratory Standards (2001). Method for dilution antimicrobial susceptibility tests for bacteria that grow aerobically. Approved standard M7-A5. NCCLS, Wayne, Pa.

Overhage J, Campisano A, Bains M, Torfs EC, Rehm BH, Hancock RE (2008). Human host defense peptide LL-37 prevents bacterial biofilm formation. Infect .Immun. 76:4176-4182.

Reddy KM, Feris K, Bell J, Wingett DG, Hanley C, Punnoosea A (2007). Selective toxicity of zinc oxide nanoparticles to prokaryotic and eukaryotic systems. Appl. Phys. Lett. 90:213902/1-213902/3.

Roberts SK, Wei GX, Wu CD (2002). Evaluating biofilm growth of two oral pathogens. Lett. Appl. Microbiol. 35:552-556.

Saleh S, Taha MO, Haddadin RN, Marzooqa D, Hodali HA (2011). Preparation of Silver- and Zinc-Doped Mullite-Based Ceramics Showing Anti-Bacterial Biofilm Properties. Molecules 16:2862-2870.

Sarin P, Yoon W, Haggerty RP, Chiritescu C, Bhorkar NC, Kriven WM (2008). Effect of transition-metal-ion doping on high temperature thermal expansion of 3:2 mullite-An in situ, high temperature, synchrotron diffraction study. J. Eur. Ceram. Soc. 28:353-365.

Shanthi M, Sekar U (2009). Multi-drug resistant Pseudomonas aeruginosa and Acinetobacter baumannii infections among hospitalized patients: risk factors and outcomes. J. Assoc. Physicians India 57:636, 638-40, 645.
Singh V, Arora V, Alam MJ, Garey KW (2012). Inhibition of Biofilm Formation by Esomeprazole in Pseudomonas aeruginosa and Staphylococcus aureus. Antimicrob. Agents Chemother. 56:4360-4.

Soto-Barreras U, Olvera-Rubio JO, Loyola-Rodriguez JP, ReyesMacias JF, Martinez-Martinez RE, Patiño-Marin N, MartinezCastañon GA, Aradillas-Garcia C, Little JW (2012). Peripheral Arterial Disease Associated with Caries and Periodontal Disease. J. Periodontol. pp. 1-13. (doi:10.1902/jop.2012.120051).

Tang H, Cao T, Wang A, Liang X, Salley SO, McAllister JPII, Ng KYS (2007). Effect of surface modification of silicone on Staphylococcus epidermidis adhesion and colonization. J. Biomed. Mater. Res. A. 80:885-894.

Tao L, Hu B, Rosenthal VD, Gao X, He L (2011). Device-associated infection rates in 398 intensive care units in Shanghai, China: International Nosocomial Infection Control Consortium (INICC) findings. Int. J. Infect. Dis. 15, e774-80.

Yan L, Boyd KG, Grant BJ (2002). Surface attachment induced production of antimicrobial compounds by marine epiphytic bacteria using modified roller bottle cultivation. Mar. Biotechnol. (NY). 4:356366 . 